\title{
RIGHT TO VOTE DURING AN ECONOMIC STRIKE
}

One provision of the Taft-Hartley Act, urged by its supporters as simple common sense $e^{x}$ and damned by its critics as "calculated to produce and prolong strife and to defeat collective bargaining," ${ }^{2}$ states in effect that if a representation election is held during an economic strike, permanent replacements hired by the employer shall vote instead of the strikers whose jobs they fill. ${ }^{3}$ The underlying problem is acute because the two groups, the replacements and the displaced strikers, possess diametrically conflicting interests in the election yet each can advance a good claim of a right to vote. Three recent applications of this provision by the National Labor Relations Board plus current congressional re-examination of the national labor policy have aroused new interest in the pertinent issues. 4

As between the two groups, the right of the strikers to vote in a representation election held during a strike, excluding any question of replacements, is well established.5 A basic principle of the National Labor Relations Act is that the peaceful settlement of industrial disputes will be enhanced by the promotion of collective bargaining. ${ }^{6}$ In order to assure that collective bargaining will not be interrupted during the critical time a strike is in progress, the Act defines strikers as "employees" so that the employer's obligation to bargain shall continue. ${ }^{7}$ It follows that if a representation election is held during a strike, the strikers must be eligible to vote and the Board has so held. ${ }^{8}$ In the Sartorius case in 1938 the Board was first presented with the contention that replacements hired during a strike should also be allowed to vote. 9 By holding in that case that the strikers

x Senate Report on S. II26, 80th Cong. Ist Sess., at 25 (I947).

"Senate Minority Report No. 105, Pt. 2, on S. II26, 80th Cong. Ist Sess., at Io (I947).

3 "Employees on strike who are not entitled to reinstatement shall not be eligible to vote." Labor-Management Relations Act § 9(c)(3), 6I Stat. I43 (1947), 29 U.S.C.A. § I59 (Supp., 1947).

4Triangle Publications, Inc., Station WFI-TV, 23 L.R.R.M. II 44,80 N.L.R.B. No. I32 (1948); Pipe Machinery Co., 22 L.R.R.M. I510, 79 N.L.R.B. No. I8I (1948), pursuant to 2 I L.R.R.M. II 78, 76 N.L.R.B. No. 37 (1948); Times Square Stores Corp., 22 L.R.R.M. 3 I 73, 79 N.L.R.B. No. 50 (1948).

5 Wicaco Machine Corp., 69 N.L.R.B. 74I (r946); Burton-Dixie Corp., 29 N.L.R.B. 444 (194I); The Harris-Hub Bed \& Spring Co., I3 N.L.R.B. I236 (1939).

"It is declared to be the policy of the United States to eliminate the causes of certain substantial obstructions to the free flow of commerce ... by encouraging the practice and procedure of collective bargaining. ..." Labor-Management Relations Act $\S \mathrm{r}$, 6r Stat. I36 (1947), 29 U.S.C.A. $\$$ × 51 (Supp., I947). "The theory of the Act is that free opportunity for negotiation with accredited representatives of employees is likely to promote industrial peace and may bring about the adjustments and agreements which the Act in itself does not attempt to compel." NLRB v. Jones \& Laughlin Steel Corp., 30r U.S. I, 45 (1937).

7 "The term 'employee' shall include ... any individual whose work has ceased as a consequence of, or in connection with, any current labor dispute. . . " Labor-Management Relations Act § 2(3), 6r Stat. I37 (I947), 29 U.S.C.A. § I52 (Supp., I947).

${ }^{8}$ Cases cited note 5 supra.

9. Sartorius \& Co., Inc., ro N.L.R.B. 493 (1938). 
alone were eligible to vote, the Board gave renewed meaning to the importance of preserving the continuity of the bargaining process..$^{\mathrm{x}}$

Under present board policy the conflicting claims of the replacements to vote can arise only in an "economic" strike, as opposed to an "unfair labor practice" strike. ${ }^{\text {II }}$ This distinction was not found in the Wagner Act but arose in its administrative interpretation. An unfair labor practice strike is one which is induced or prolonged by an unfair labor practice on the part of the employer within the meaning of the Act.12 The economic strike is any other legitimate strike, generally for the customary purpose of securing a change in wages, hours, or working conditions. ${ }^{\mathrm{x}}$ Since the employer has committed a wrong in the unfair labor practice strike the Board orders the reinstatement of all strikers, even if this means discharging replacements hired to take their places. ${ }^{14}$ The unfair labor practice will be inoperative to change the majority status of the bargaining agent, ${ }^{15}$ and in an election held during the strike only the strikers will be permitted to vote. ${ }^{16}$ In the economic strike, however, since the employer himself is guilty of no misconduct under the law, the Board and the courts have consistently upheld his right to hire replacements and to retain them after termination of the dispute. This is the Mackay doctrine. ${ }^{.7}$ The replaced strikers have no

so To permit replacements to vote "might effectively foreclose the possibility of the settlement of the labor dispute, whether by the return of the striking employees to their jobs ... during the strike, or by some other settlement agreement, a possibility which the Act contemplates should not be foreclosed during the currency of the strike." A. Sartorius \& Co., Inc., to N.L.R.B. 493,495 (1938).

"However, the Senate-House conference on the Taft-Hartley Act specifically left the Board free to change its policy and hold that even unfair labor practice strikers would not be entitled to reinstatement if permanent replacements had been hired. 93 Cong. Rec. 660 r (June 5, I947). Under Section 9(c)(3), since the unfair labor practice strikers would not be entitled to reinstatement they would not be eligible to vote. This would have the effect of penalizing the workers for calling the strike instead of seeking rectification of the employer's wrong through the orderly processes of the Board.

${ }^{12}$ M. H. Ritzwoller v. NLRB, 4 F. 2 d 432 (C.C.A. 7 th, x940); NLRB v. Stackpole Carbon Co., I05 F. $2 \mathrm{~d}$ I67 (C.C.A. 3d, I939).

${ }^{3}$ Columbia Pictures Corp., 64 N.L.R.B. 490 ( 9945 ) (recognition); Firth Carpet Co. v. NLRB, I29 F. 2d 633 (C.C.A. 2d, I942) (sympathy strike); NLRB v. Mackay Radio \& Telegraph Co., 304 U.S. 333 (1938) (dissatisfaction with negotiations). The strike is presumed to be an economic strike when no unfair labor practice charges are pending before the Board. Times Square Stores Corp., 22 L.R.R.M. I373, I374, 79 N.L.R.B. No. 50 (I948). The economic strike is to be distinguished from a third class of strikes, those whose purpose is unlawful. Southern Steamship Co. v. NLRB, 3 I6 U.S. 3I (I942) (mutiny); The American News Co., Inc., 55 N.L.R.B. I3O2 (r944) (strike to compel employer to violate the Federal Stabilization Act); NLRB v. Sands Mfg. Co., 306 U.S. 332 (1939) (violation of contract). The Taft-Hartley Act has added, inter alia, the secondary boycott, strikes in defiance of the Board's certification, and the jurisdictional dispute. Labor-Management Relations Act $\S 8(\mathrm{~b})$ (4), 6r Stat. r40 (I947), 29 U.S.C.A. § I58 (Supp., r947).

\footnotetext{
${ }_{14}$ Louisville Refining Co., 4 N.L.R.B. 844 (1938).

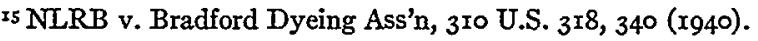

${ }^{76}$ Longhorn Roofing Products, Inc., 67 N.L.R.B. 84 (r946).

${ }_{77}$ NLRB v. Mackay Radio \& Telegraph Co., 304 U.S. 333 (I938).
} 
right to reinstatement. ${ }^{18}$ Since the replacements are bona fide employees, they can claim as much right to vote as the strikers. In the Wurlitzer case in I94 $\mathrm{r}$ the Board, having undergone a change in personnel, ${ }^{19}$ overruled the Sartoritus decision by holding both groups eligible to vote. ${ }^{20}$

The Taft-Hartley law completed the gamut of possible positions by providing that the right of permanent replacements to vote is superior to that of the displaced strikers. ${ }^{2 x}$ The congressional majority supported this pro-management position on the ground that the employer should not be obligated to bargain with persons who are not on the job and have no expectancy of employment.22

The major problem introduced by the present law is how to determine when the replacements are sufficiently "permanent" so as to take precedence over the strikers. In ordering the election to be held the Board, for administrative convenience, considers both strikers and replacements presumptively eligible to vote subject to challenge. ${ }^{23}$ The challenged ballots are only passed upon if the voting is close and if their number is sufficient to affect the results. ${ }^{24}$ The recent Pipe Machinery decision gave the Board its first opportunity to delineate what the tests of permanency might be. ${ }^{25}$ In that case the plant had been reopened three months after the strike began, and within the next three months full operations had been resumed. Six months thereafter the Board ordered the election; it was relatively easy therefore to decide that the replacements were permanent. The Board took into consideration the following factors: none of the strikers had ever made unconditional application for return to work; after resuming operations the company had attempted to induce the strikers to return; the replacements testified that they had been hired on a permanent basis and planned to continue with the company; in their previous employment they had done the same or similar work; and they had been hired from the geographical area in which the plant was located. Although it agreed that the replacements were "permanent" in this case, the Board ruled that unilateral declarations by the employer that the work is permanent are not by themselves determinative. ${ }^{26}$

\footnotetext{
18 "It has long been established that economic strikers who have been permanently replaced are not entitled to reinstatement." Pipe Machinery Co., 22 L.R.R.M. 1510, 79 N.L.R.B. No. I8I (r948).

19 Harry A. Millis replaced J. Warren Madden as chairman, and Wm. M. Leiserson replaced Donald Wakefield Smith as member.

${ }^{30}$ Rudolph Wurlitzer Co., 32 N.L.R.B. I63 (r94r). $\quad$ 21 Note 3 supra.

${ }^{22}$ See 93 Cong. Rec. 3834 (April 23, I947). By eliminating the right of displaced strikers to vote, Congress removed the apparent absurdity of the Wurlitzer rule under which more votes were cast than there were jobs to fill. An excellent discussion of this issue is found in Rudolph Wurlitzer Co., 32 N.L.R.B. I63, I69, I7I (I94I).

${ }^{23}$ Pipe Machinery Co., 2I L.R.R.M. II78, 76 N.L.R.B. No. 37 (I948); Solar Electric Corp., 22 L.R.R.M. I03I, 77 N.L.R.B. No. 77 (1948): Boaz Mills, Inc., 22 L.R.R.M. I322, 78 N.L.R.B. No. 153 (1948).

24 Cases cited note 23 supra.

2s Pipe Machinery Co., 22 L.R.R.M. I5IO, 79 N.L.R.B. No. I8I (I948).

${ }^{26}$ Ibid.
} 
The mere fact that an election is called during a strike means that prior to the strike no union had been certified as the collective bargaining agent. Had the striking union been so certified, the employer would have been obligated to bargain with it for at least a year. ${ }^{27}$ With certification the pre-strike status quo is preserved during the strike insofar as the collective bargaining obligation is concerned. If a non-certified union represents a clear majority of the employees before a strike is initiated the employer is under a duty to bargain and cannot raise lack of certification as a defense. ${ }^{28}$ But after an economic strike has begun, under the Wurlitzer and Taft-Hartley rules, the employer is able to change this pre-strike status quo, since the replacements he is entitled to hire are also able to vote in a representation election held during the strike. ${ }^{29}$ In this manner the Wurlitzer and Taft-Hartley doctrines operate in effect to penalize the union for not having safeguarded itself with certification before calling the strike. This result seems harsh, since the often time-consuming certification procedures of the Board are usually an inadequate substitute for the advantages of a strategically timed strike.

The burden of obtaining certification which is thus placed on the union should be contrasted with the various rights and duties of the employer under other pre-strike situations. Where the majority status of the union is in reasonable doubt, the employer may refuse to bargain until an election is held, ${ }^{30}$ provided he makes a timely objection in good faith. ${ }^{3 x}$ Further, if two or more unions are contending for representation, the employer is forced to wait for the certification of one or the other, because it would be an unfair labor practice to sign a contract with, or demonstrate a preference for, either union..$^{32}$ The Board, however, has refused to declare a strike unlawful in either of these situations. ${ }^{33}$

Regardless of the status of the union before the strike began, the employer

${ }^{27}$ The Taft-Hartley Act provides that no more than one election may be held in any

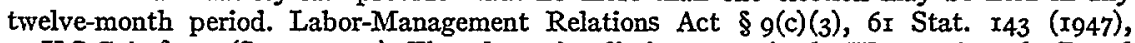
29 U.S.C.A. $\S 159$ (Supp., I947). Thuugh no time limit was set in the Wagner Act, the Board held the certification good for a reasonable time, usually a year. Kimberley-Clark Corp, 6r N.L.R.B. 90 (I945).

${ }^{28}$ NLRB v. Dahlstrom Metallic I oor Co., II2 F. 2d 756 (C.C.A. 2d., 1940).

29 The way in which the status quo changes can be illustrated by a simple example. Suppose a work force of 100,70 of whom go out on strike. It can be assumed that the 30 employees remaining on the job and any replacements hired will vote against the striking union. Under the Taft-Hartley provision the union will lose its majority status and therefore the election if 2I replacements have been hired. Under the Wurlitzer doctrine the same result will follow when $4^{\mathrm{r}}$ replacements are hired. Thus, under the Wurlitzer rule each replacement is onehalf as effective in changing the pre-strike picture as under the Taft-Hartley Act.

30 Surpass Leather Co., 2I N.L.R.B. I258 (I940).

${ }^{3 x}$ NLRB v. Remington Rand, Inc., 94 F. $2 d 862$ (C.C.A. 2 d, I938).

${ }_{32}$ Midwest Piping \& Supply Co., Inc., 63 N.L.R.B. 1060 (I945); Keystone Steel and Wire Co., 62 N.L.R.B. 683 (1945); Elastic Stop Nut Corp., 5I N.L.R.B. 694 (I943).

33 Granite Textile Mills, Inc., 2I L.R.R.M. I216, 76 N.L.R.B. No. 93 (1948) (single union); National Silver Co., 7 I N.L.R.B. 594 (1946) (competing unions); Columbia Pictures Corp., 64 N.L.R.B. 490 (1945) (competing unions). This would be a strike for "recognition." 
secures impressive gains if the striking union loses the election. The morale of the strikers will be dealt a serious blow, and potential replacements will be more willing to come to work. Not only will the strike be broken but the employer will handily berid of what he regards as a disagreeable union. ${ }^{34}$ And, what is most important, immediately after certification of the new union the strikers become guilty of the unfair labor practice of acting to compel recognition in defiance of a board certification, ${ }^{35}$ and the union is subject to a mandatory court injunction as well as liability for damages. ${ }^{36}$ Even under the Wagner Act, although no injunction could be secured, 37 the employer was permitted to discharge all workers participating in a strike of this kind..$^{8}$ These are tempting inducements to the employer to postpone settlement until fifty-one per cent replacements are hired and the election is held.

The chief union objection to Section 9 (c)(3) emphasizes the effect on the strike of allowing the replacements to vote. Once the strike begins, it is important that collective bargaining continue unimpaired in order to reach a settlement as early as possible. Most strikes are ended in this manner. ${ }^{39}$ To put into the employer's hands the power to cut down the striking union's majority status one by one as each new replacement is hired, until he shall no longer be obligated to bargain, is to give him a powerful inducement, not to settle the strike, but to prolong it. Even an employer acting in good faith will find it difficult to know from day to day, as additional replacements are hired and additional strikers abandon the strike, with whom the law obligates him to deal. $4^{\circ}$ The effectiveness of collective bargaining as a means for peacefully settling labor disputes is thus seriously impaired.4 ${ }^{\mathrm{I}}$

34 When the officers of the striking union have not filed non-Communist affidavits, the employer is apparently free actively to support a competing union, since unfair labor practice charges filed by members of the striking union will be dismissed. Times Square Stores Corp., 22 L.R.R.M. I373, 79 N.L.R.B. No. 50 (I948); H. O. Canfield Co., 2x L.R.R.M. I2I7, 76 N.L.R.B. No. 92 ( 1948$)$.

35 Labor-Management Relations Act $\$ 8(b)(4)(C)$, 6I Stat. I $_{40}$ (I947), 29 U.S.C.A. $\$ 158$ (Supp., I947).

${ }^{6} \mathrm{Ibid}$, at $\$ \S \mathrm{ro}(\mathrm{x}), 303$.

37 Yoerg Brewing Co. v. Brennan, 59 F. Supp. 625 (Minn., 1945). The Norris-LaGuardia Act bars the injunction. This opinion contains an excellent discussion of the problem.

${ }^{8}$ Thompson Products, Inc., 72 N.I.R.B. 886 (I947).

39 See A. Sartorius \& Co., Inc., Io N.L.R.B. 493, 494 (1938), and Edwin S. Smith's dissent, Rudolph Wurlitzer Co., 32 N.L.R.B. 163, I72 (I94I).

${ }^{10}$ See dissent, Rudolph Wurlitzer Co., 32 N.L.R.B. I63, I72 (r94r).

${ }_{4}$ The Senate Minority Report stressed this argument. "We deem it highly undesirable, because it enables an employer to secure the rejection of an established bargaining agent at the very time that the public interest makes it particularly urgent that collective bargaining continue. ... Anti-union employers are ... encouraged to refuse settlement of disputes in order to bring about strikes and thereby secure the defeat of the collective bargaining representative. We can think of few provisions in this bill better calculated to produce and prolong strife and to defeat collective bargaining." Senate Minority Report No. x०5, Pt. 2, on S. I 126, 8oth Cong. Ist Sess., at ro (1947). 
A second objection to the rule of the Taft-Hartley Act is that it allows the employer to use the representation procedure to enhance his economic power in the continuing conflict between management and labor. This rule permits the employer, after having hired fifty-one per cent replacements, to call for an election which will immediately break both the union and the strike and cut off remaining economic weapons which the union might still be able to wield. ${ }^{22}$ Without the election, a strike is not necessarily ended merely because the employer has hired fifty-one per cent replacements. For example, the remaining forty-nine per cent of the strikers might include certain key skilled men, difficult to replace; or continued picketing by the union may cause a serious loss of business. 43 Effects similar to these have caused organized labor to assert that the provision in question, Section 9 (c)(3), places such a hazard on the right to strike as to make the guarantees of that right in the Act a nullity. 44

In any re-examination of a striker's right to vote, one possible formula Congress might adopt would be to apply different rules depending on the relations of the parties at the beginning of the strike. Thus, for example, the TaftHartley rule, which operates to some extent to penalize the union for not securing certification before calling the strike, might be applied where two rival unions were contending for representation or where the majority status of the striking union was not clear and the employer raised this objection in good faith at the proper time. On the other hand, the Sartorius rufe, permitting only strikers to vote, would be applied when the majority status of the union was clear before the strike, or the employer did not in good faith insist on an election. before he went ahead with collective bargaining. Such a rule, however, is subject to the criticism that it further complicates the strike picture when simplicity in defining the exact legal position of both sides is itself a virtue.

There is a second possible alternative to Section $g(c)(3)$. While the strike is still current, only the strikers might be permitted to vote, but after the employer had for all practical purposes terminated the strike by the exercise of his right to hire replacements and resume operations, the right to vote would pass to the replacements and unreplaced strikers. This provision might read: "Replacements hired during a strike shall not be eligible to vote unless the strike has, for representation purposes, been terminated."

The suggested rule is not new. It was implicit in the Sartorius doctrine, under

${ }_{42}$ The Taft-Hartley Act permits the employer to file a petition for an election, following a claim for recognition by one or more individuals. Labor-Management Relations Act $\S 9(\mathrm{c})(\mathrm{x})(\mathrm{B}), 6 \mathrm{I}$ Stat. $\mathrm{r}_{43}$ (I947), 29 U.S.C.A. $\S$ I59 (Supp., 1947). Employer petitions were also permitted under the Wagner Act. N.L.R.B. Rules and Regulations, Series 2, effective July 14, 1939, $\$ \$ 203 \cdot x-203.2$, 4 Fed. Register $3^{1} 39$ (I939).

${ }^{43}$ Cf. Yoerg Brewing Co. v. Brennan, 59 F. Supp. 625 (Minn., I945); McPherson Hotel Co. v. Smith, I27 N.J. Eq. I67, I2 A. 2 d I36 (I940); E. M. Loew's Enterprises, Inc. v. International Alliance of Theatrical State Employees, r25 Conn. 39x, 6 A. 2d 32I (I939).

${ }^{44}$ See the union argument in Pipe Machinery Co., 22 L.R.R.M. I5IO, 79 N.L.R.B. No. I8I (I948). 
which the question of termination was explicitly decided at least once in the affirmative. 45 Like all attempted solutions, this answer raises its own problems, the chief of which is to determine when the strike is "terminated." The modifying phrase, "for representation purposes," is included in order to emphasize that termination should be found only when collective bargaining with the strikers can no longer serve a useful purpose and when none of the effective economic weapons of the union remains to be cut off by the election. Factors to be considered should probably include: the reasonable expectancy of settlement; $4^{46}$ the continued economic loss to the employer and his resumption of normal operations; the continued evidence of strike activity, such as the degree of picketing effort; whether strike benefits are continued; and the percentage of strikers who have secured permanent employment elsewhere or returned to work. ${ }^{47}$ The question of termination is probably no more difficult to decide than the present problems of who is a "permanent replacement" and which of the strikers have been replaced. $4^{8}$ The Board has already had to decide the question in a few cases, ${ }^{49}$ as state courts have had to decide the similar question of whether a "labor dispute" is terminated within the meaning of various state statutes..$^{50}$

45 Standard Insulation Co., Inc., 22 N.L.R.B. 758 (1940).

${ }_{46}^{6}$ Since the election forecloses a settlement, the expectancy of settlement would seem to be a relevant factor, although to regard it as such might penalize the employer who is acting in good faith by continuing to bargain. Some state courts have considered the question. E. M. Loew's Enterprises, Inc. v. International Alliance of Theatrical Stage Employees, 125 Conn. 39I, 6 A. 2d 32I (I939). And in federal courts under the Wagner Act, NLRB v. Remington Rand, Inc., 94 F. $2 d$ 862, 872 (C.C.A. 2d, 1938) (the Act "does not require further negotiation after it becomes apparent that a settlement is impossible").

47 "Among the criteria for determining whether a strike continues in existence are the employer's filling of positions left vacant by the strikers, his resumption of normal operations, and the continuance of concerted strike activities by the workers." Standard Insulation Co., Inc., 22 N.L.R.B. 758 (I940).

${ }^{8}$ Eight months elapsed between the order of election and the decision on the challenged votes in the Pipe Machinery case. By the date of decision the strike had in effect been ended. Pipe Machinery Co., 22 L.R.R.M. I5IO, 79 N.L.R.B. No. 18I (1948).

49 Standard Insulation Co., Inc., 22 N.L.R.B. 758 (r940) (strike held terminated where only sporadic picketing continues, strikers have offered to return to work and twelve of some fifty have been re-employed, and normal operations have been resumed); Lloyd Hollister, Inc. 68 N.L.R.B. 733 (1946) (strike found still to be current where picket lines have been maintained, union continues to pay strike benefits and retains company on "unfair list," and company has continued to meet with union in effort to settle the strike); Standard Lime \& Stone Co., I7 N.L.R.B. I47 (r939) (strike held terminated where there has been no strike activity for four years and litigation has not been continuous during that time).

so McPherson Hotel Co. v. Smith, I27 N.J. Eq. 136, I2 A. 2d I36 (1940) (where all strikers replaced, though total employed is less than before because admittedly overstaffed previously, but hotel is operating at considerable financial loss, strike is not terminated within meaning of statute prohibiting injunction against picketing in a labor dispute); Newark International Baseball Club, Inc. v. Theatrical Managers, Agents \& Treasurers' Union, I26 N.J. Eq. 520, Io A. 2d 274 (1940); Blonder v. United Retail Employees of Newark, I28 N.J. Eq. 4I, I5 A. 2d 826 (1940) (picketing enjoined where "no good reason for it exists"); E. M. Loew's Enterprises, Inc. v. International Alliance of Theatrical Stage Employees, I25 Conn. 39r, 6 A. 2d 321 (1939) (the underlying test is whether there is a "reasonable expectation of settlement, 
To give proper effect to the rule, the Board would have to be on guard against a premature finding that the strike is ended by placing an unwarranted reliance on precedents based on this or other statutes covering termination of a strike for other purposes. Under the proposed rule necessary administrative delay does not operate to confuse the collective bargaining obligation, since this obligation remains unchanged until the decision is announced. The operation of the Wurlitzer and Taft-Hartley rules creates an interim period of confusion during which the employer's obligation to bargain is suspended for want of an ascertained party with whom to deal.

\section{PROTECTION FROM DEFAMATION IN CONGRESSIONAL HEARINGS}

One of the aims of the House Committee on Un-American Activities ${ }^{x}$ has been to "permit the greatest court in the world-the court of American public opinion-to have an undirected, uncensored, and unprejudiced opportunity to render a continuing verdict on all of its public officials and to evaluate the merit of many in public life...." The marked skill and success of the Committee in pursuing this course have lead to widespread controversy. ${ }^{3}$ Regardless of the

but other factors are the extent of resumption of normal operations, the loss of business, and the tort notion of whether there remains someone to benefit from the activity or whether its object has "become no more than an effort to injure the employer"); The Determination of When a Strike Is Ended, $38 \mathrm{Col}$. L. Rev. 676 (9938), noting Mode Novelty Co. v. Taylor, r22 N.J. Eq. 593, x95 Atl. 8r9 (1937) ("A strike is terminated when the places of strikers have been filled with competent men, and the employer's business is operating in a normal manner and to a normal extent"); cf. Rest., Torts $\$ 776$, comment b. (r939).

I Originally created as a special committee by H. Res. 282, 75th Cong. 3 d Sess. (I938), the Un-American Activities Committee was continued by successive resolutions until I945. H. Res. 26, 76th Cong. Ist Sess. (I939); H. Res. 321, 76th Cong. 3d Sess. (x940); H. Res. 9o,

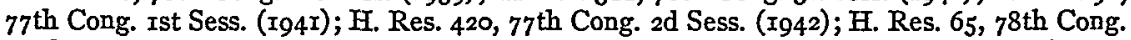
Ist Sess. (I943). It was made a standing committee by H. Res. 5, 79th Cong. Ist Sess. (1945), and has since been authorized by the Legislative Reorganization Act of $1946 \S \mathrm{r} 2 \mathrm{I}(\mathrm{b})(\mathrm{x})(\mathrm{q})$, 60 Stat. 828 (I946). The purposes of the Committee were defined in these enactments as follows: "The Committee on Un-American Activities, as a whole or by subcommittee, is authorized to make from time to time investigations of (i) the extent, character, and objects of unAmerican propaganda activities in the United States, (ii) the diffusion within the United States of subversive and un-American propaganda that is instigated from foreign countries or of a domestic origin and attacks the principle of the form of government as guaranteed by our Constitution, and (iii) all other questions in relation thereto that would aid Congress in any necessary remedial legislation."

${ }^{2}$ Interim Report of the House Committee on Un-American Activities on the Hearings regarding Communist Espionage in the United States Government, 8oth Cong. 2d Sess., at r-2 (1948).

3 The professed aims of the Committee, its sincerity in espousing them, and the procedures adopted have all been criticized. The leading work on procedure is Ogden, The Dies Committee (2d ed., I945), while differing viewpoints as to the Committee's worth are presented by Zahn, Hollywood on Trial (I948); Cohn, Those Investigating Committees, reproduced in Thought Control in U.S.A. 40 (I947); Letter from the members of the Yale Law School faculty to the President of the United States, the Secretary of State, and the Speaker of the House of Representatives, reprinted in "Lawyer Schools" or "Policy Science"? Yale Law School's Manifesto Stirs Debate, 34 A.B.A.J. I5, I6 (r948); Gelhorn, Report on a Report of the House Committee 